\title{
THE PERCEPTION ON THE CONTRIBUTION OF ISLAMIC BANKS AND ISLAMIC WINDOWS TOWARDS THE GROWTH OF NIGERIAN ECONOMY
}

\author{
Jibril Musa Talba', Ibrahim Mohammed Lawal ${ }^{2}$ and Umar Babagana Imam ${ }^{3}$ \\ ${ }^{1}$ University of Maiduguri, Borno State, musatalba@gmail.com \\ ${ }^{2}$ University of Maiduguri, Borno State, ibrahimruqqy@gmail.com \\ ${ }^{3}$ Borno State Community \& Social Development Agency, Borno State, umarb@gmail.com
}

\begin{abstract}
This study investigates the contribution of Islamic banks and Islamic windows to the growth of the Nigerian economy. Data were obtained using structured questionnaires. 379 copies of questionnaires were administered based on the sample size obtained via the use of Taro Yamane formula. 367 questionnaires were successfully retrieved. Variables such as deposit activities, loan activities, and perception of bank employees were also adopted as explanatory or independent variable and dependent variable respectively. To support the study hypothesis were also formulated. For the analysis, measures of central tendency (tables, frequency and percentages) and inferential statistics (Logit Regression) were used. The result revealed that the variables (i.e. deposit and loan activities) have a positive impact on the growth of Nigeria's economy because the probability values of the variables $(\mathrm{P}=0.003$ and 0.019$)$ were less than alpha $(\alpha=0.05)$ level of significance. In other words, this implies that Islamic banks and windows have largely supported private consumption, business investments of its customers, aid government spending via sharia bonds (sukuk) to fund developmental projects of its customers. The study concludes that Islamic banks and windows have contributed towards the growth of the Nigeria's economy. Furthermore, the study recommends that there is need for creating the necessary legal framework to ensure its smooth operations, intensify efforts on creating public awareness, rolling out more sharia compliant products that can take care of the peculiarities that exist in business environment and training and retraining of staff on effective Islamic banking.
\end{abstract}

Keywords: Islamic Bank, Islamic Window, Economic Growth, Sharia, Perception. JEL Classification: G1; G21; O10.

\author{
Article history: \\ Received : June 13, 2019 \\ Revised : June 19, 2019 \\ Accepted : July 03, 2019 \\ Available online : November 1, 2019 \\ https:doi.org/10.21098/jimf.v5i2.1071
}




\section{INTRODUCTION}

The global financial crisis of 2007-2008 created awareness of the weakness of conventional banking system. More importantly, the crisis adversely affected many giant conventional financial institutions around the world such as Lehman's Brothers of United States of America and Union Bank of Switzerland (UBS). However, the potential of Islamic banks against the crisis made it more appealing beyond the Muslim world. This is because many countries deemed it necessary to search for a banking system that can withstand the test of time. As a result, the debate about the practicability of Islamic banking has not only grown but has considerably widened.

The origin of Islamic banking can be traced to Egypt in 1963 when the Mit Ghamr Saving bank in the Northern Delta region of the Nile was established by a renowned Economist, Ahmad El-Naggar, followed by a cooperative bank in Pakistan in 1965. Similarly, the Islamic Development bank (IDB) in Saudi Arabia, Faisal Islamic Bank in Egypt and Sudan was also established in 1975 and 1977 respectively.

Islamic banking is now considered as a well-known term and has emerged as one of the most important and fast growing industry with over 250 Islamic banks and window spread in more than 75 countries of the world (Fada, 2012). However, the Islamic banking assets is estimated to worth USD1.496 trillion as at first half of 2015 which is about $80 \%$ of the total sharia compliant asset having grown from USD1.476 trillion as at first half in 2014 (IFSB Report, 2016). Subsequently, across African regions, Islamic banking is gradually gaining momentum because as at 2013, there were about 56 Islamic banks and 18 Islamic bank windows in over 15 African countries. (Issa et al, 2013). Below is the performance snapshot of the Islamic banking asset globally.

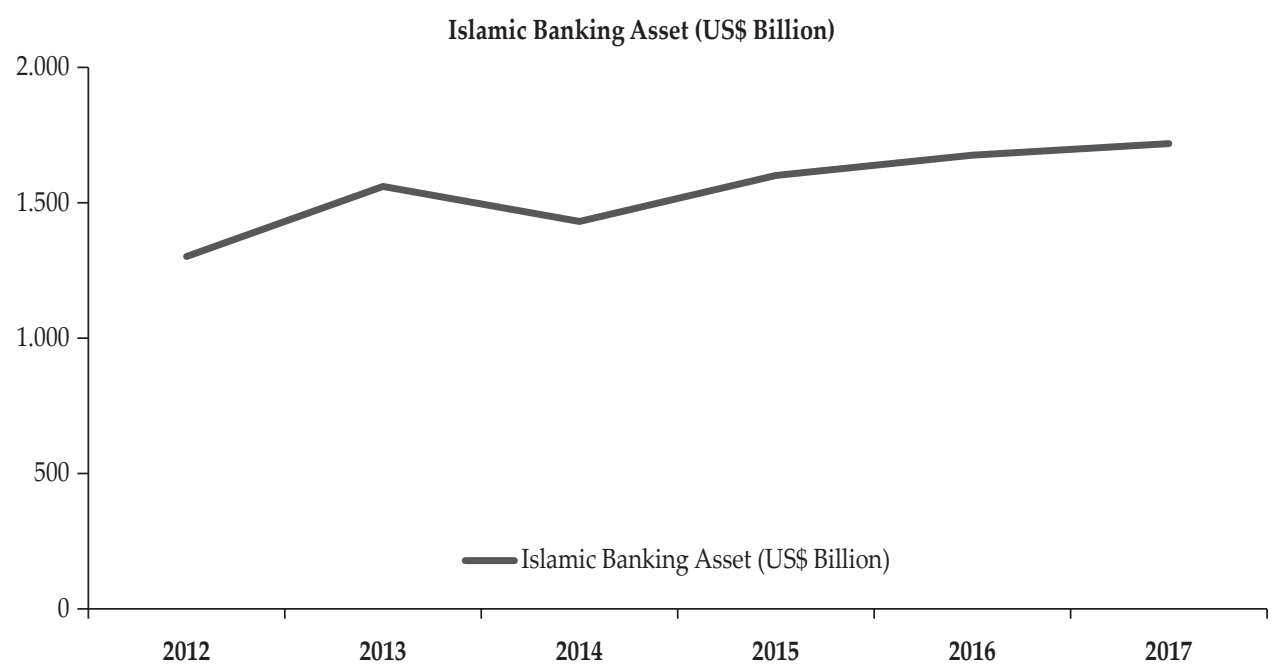

Source: Islamic Finance Development Report- ICD Thomson Reuters (2018)

Figure 1.

Islamic Banking Asset (2012-2017) 
Figure 1 depicts the growth of Islamic banking asset has a Compound Annual Growth Rate (CAGR) of about 5\% and its asset stood at US\$1,721 billion as at the end of 2017. This growth recorded by Islamic banks over the years has demonstrated its potentials for future growth despite at its infant stage and stiff competition from the conventional banks.

More so, in Nigeria the evolution of Islamic banking can be traced back to as far as 1991 when the Bank, Insurance and other Financial Institution (BOFIA) act was amended. This gave birth to an Islamic window in 1992 that was practiced by Habib bank, which is still operational in Platinum Habib bank (Now Keystone Bank). In addition, an approval in principle was granted to Jaiz bank to operate full pledge Islamic bank in the country in 2003, but could not commenced operations before the recapitalization of banks in 2005. However, no success story was recorded owning to the absence of formidable regulatory framework. The Central Bank of Nigeria (CBN) in 2011 released a framework for Non-Interest Financial Institutions (NIFI's) which further categorized Non-Interest Financial Institutions into two (2): Islamic Financial Institutions and Other Non Interest Financial Institutions.

Currently, there exist only one full-fledged Islamic bank in Nigeria known as Jaiz bank Plc, and three Conventional Islamic bank windows: Keystone Bank, StanbicIBTC Bank, and Sterling Bank. Since, its commencement of operations in 2012, these banks were able to grow their major key performance indicators but due to data constraint from the conventional Islamic banks, the figures for the full fledge Islamic bank is presented as thus.

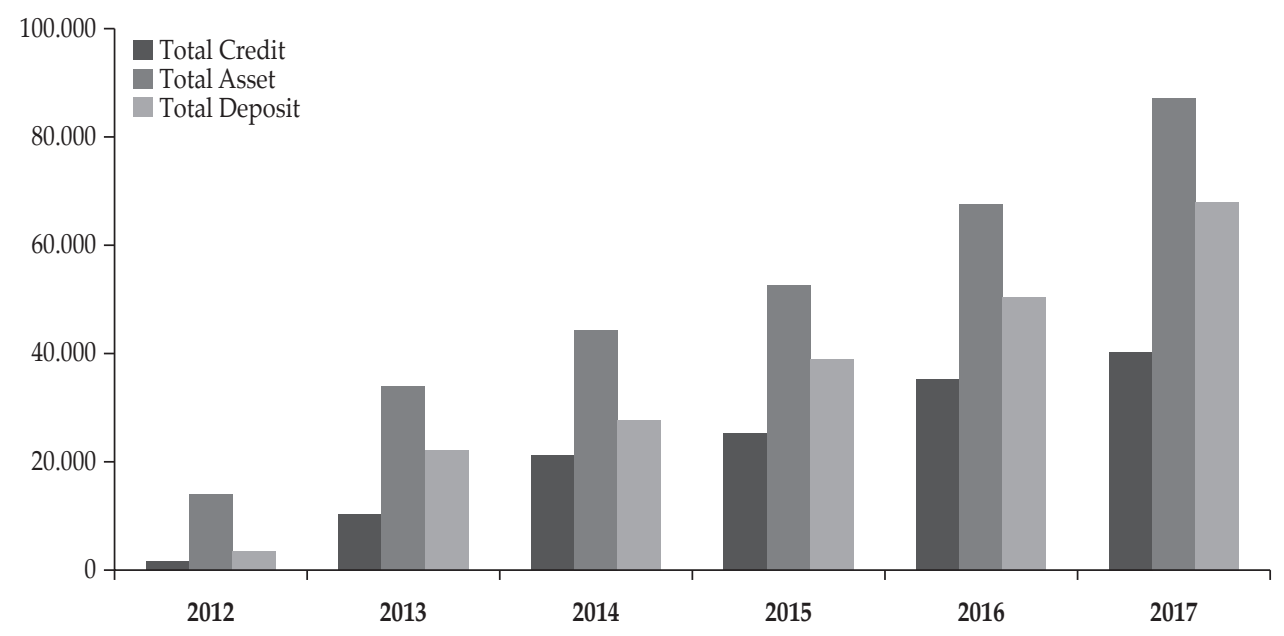

Source: Jaiz Bank Plc Annual Report, 2013 2014, 2015, 2016 and 2017

Figure 2.

Total Credit, Total Asset, Total Deposit and Performance-2012-2017 in N’M (Jaiz bank Plc)

Figure 2 depicts that all the key performance indicators such as total credit, total asset and total deposit has been witnessing consistent growth under the 
period under review. Consequently, it is pertinent to note that Islamic banks and windows are considered as a mechanism for financial intermediaries because they mobilize funds from the surplus areas and channel it to the deficit areas. However, these activities must not involve any elements of interest, gambling (maysir), uncertainty (gharar), unethical business and investment as well as adherence to the principle of profit and loss. These activities can be further x-rayed in their deposit (savings) and credit or loan activities that they engaged in. But these functions been performed by these banks have attracted questions as to whether or not they have been able to live up to their expectations along such lines towards stimulating growth? It is against this background that this paper intent to analyze the perception Bankers on the contribution of Islamic banks and windows towards the growth of Nigerian economy. In fulfilling this aim, the following specific objectives are developed.

I. To evaluate the perception on the role of loan activities carried out by Islamic banks and Islamic windows towards the growth of Nigerian economy.

II. To evaluate the perception on the role of deposit activities carried out by Islamic banks and Islamic windows towards the growth of Nigerian economy.

\section{LITERATURE REVIEW}

\subsection{Conceptual Review}

\subsubsection{Islamic Bank}

Ahmed (2008) posited that Islamic banks are financial institutions whose rules and procedures clearly state commitment to principles governing Islamic sharia law, which bans payment or receipt of interest on its operations. An Islamic bank, just like any conventional bank is a financial intermediary and at the same time a trustee and custodian of people's money or financial assets with main dissimilarities being the payoff of its clients is a share in profits and or loss while the principles of sharia govern its operations (Dar and Presley, 1999).

However, a well acceptable definition of the concept was given by the General Secretariat of the Organization of Islamic Conference and the Islamic Development bank (Paramanik, 2009), which is defined as thus" is a financial institution whose statutes, rules and procedures expressly state its commitment to the principles of Islamic Sharia (jurisprudence) and forbids the receipt and payment of interest on any transaction.

Central Bank of Nigeria (2011), categorized Islamic banking amongst its specialized banks under the new CBN banking model. Non-interest banking and finance models are broadly categorized into two: Non-interest banking and finance based on Islamic commercial jurisprudence; Non-interest banking and finance based on any other established non-interest. However, emphasis will be placed on the Non-interest banking and finance model that is based on Islamic commercial jurisprudence that also refers to Islamic banks and windows in the course of this study. 


\subsubsection{Islamic Window}

Azmi (2015) defined an Islamic window as a separate department within a conventional bank, which operates under the strict guidance by an independent Sharia Advisory Board to develop and offer Islamic financial products to the clients that demand such products. An Islamic window may offer its products or services through conventional branches or dedicated Islamic branches of the conventional banks. In addition, Islamic windows refer to a department of a conventional bank offering Islamic financial services (Islamic Finance WIKI, 2018).

\subsubsection{Perception}

George and Jones (2005) sees perceptions as the process by which an individual select, organize and interpret the input from their senses to give meaning and order around them. Perception is made up of components: the perceiver, target population and the situation. The factors that influence the perceiver are as thus; schema which is the organization and interpretation of information based on past experiences and knowledge, the motivational state which has to do with needs, values and desires of a perceiver at the time of perception and the mood which involves emotions of the perceiver at the time of perception.

\subsubsection{Economic Growth}

Economic growth according to Lipsey (1986) is the positive trend in the nation's total output over long term. This implies a sustained increase in Gross Domestic Product (GDP) for a long time.

\subsection{Theory}

This study is underpinned on the Harrod-Domar Model, two gap models and the Gibson theory of direct perception. The Harrod-Domar model stresses the importance of savings and investment as key determinant of growth. In other words, the model suggests that the growth rate of an economy depends on the level of national savings (S) and the productivity of capital investment (i.e., capital output ratio). This model tends to fit into the theoretical basis for this study because banks as financial intermediary, they mobilize funds from the surplus area and channel it to the deficit area to stimulate growth. This intermediation by banks can be linked to the savings and investment activities as stressed by the model.

It is in lieu of this assertion of the H-D Model that supported the need to derive the variables of the model along the deposit and loan activities of the bank's operations. More so, the two-gap model is an extension the Harrod Domar model. The model stressed that for an economy to achieve growth and development, they must fill two gaps: savings and investments gaps.

However, on the perception aspect, the study adopted the Gibson theory of direction perception that stressed that the cognitive apparatus was created and formed by a long evolutionary influence of external environment that is apparent in its structure and abilities. The basis of this theory is the conviction that our perception is determined by optical flows. Therefore, it is based on combination of 
these theories that the model, perception of respondents to growth as a function of deposit and loan activities gained its support.

\subsection{Previous Studies}

Tabash and Dhankar (2014a) argued that there is a strong positive association between Islamic banks' financing and economic growth in the UAE, which reinforces the idea that a well-functioning banking system promotes economic growth. Farahani, Sadr and Hossein (2012) revealed that there is a significant relationship in short-run and long run periods between Islamic financial development and economic growth. The relationship appears to be bi-directional relationship.

However, Tabash and Dhankar (2014b) posited that in the long run, Islamic banks' financing is positive and significantly correlated with economic growth in Qatar. This reinforces the idea that a well-functioning banking system promotes economic growth. Similarly, Furqani and Mulyany (2009) argued that there is evidence to support demand - following hypothesis of GDP and Islamic bank financing, i.e., where increase in GDP causes Islamic banking to develop and not vice versa. Likewise, Abduh and Chowdhury (2012) posited that Islamic banks' financing have a positive and significant relationship with economic growth both in the long and short run.

Consequently, Islamic banks and windows loan activities (financing) can be structured as equity or debt based as obtained in the works of Ahmed (2010) and Wilson (1993) which they believed that equity financing is the way forward as it can be practiced in a very moral manner. In addition, Gambo (2013) investigates customer perception of the effectiveness of service quality delivery of Islamic banks in Nigeria with Jaiz bank as a case study, which he stressed that amongst the loan instruments murabaha, mudarabah and ijarah are considered as the leading three products in order of customer's preference against other products like sharia bonds (sukuk), istisna.

By and large, security (collateral) in loan activities cannot be easily expunged as stressed in the work of Ibrahim (2016), which investigates permissibility of security (collateral) in Islamic banking lending is cogent. Kasri and Kassim (2009) investigated the impact of determining factor of saving in Indonesian Islamic banks. Their results showed that the interest rate of conventional banks have a very powerful negative effect on savings of Islamic banks. Islamic bank deposit increases with an increase in rate of return and decrease in interest rate.

Deepti and Mamta (2014) in their study depict a strong positive correlation between total saving deposits with commercial Indian GDP. Alex (2014) investigates the role of banks in capital formation and economic growth in Nigeria from 1980-2009. The result revealed that Commercial Banks Deposit Liabilities is elastic to Gross Fixed Capital Formation in Nigeria. Nwaeze, Micheal and Nwabekee (2014) investigated the impact of bank deposit mobilization and credit on economic growth from 1992 to 2011. The empirical results depicts that both total bank deposit and total bank credit exert a positive and significant impact on the economic growth of Nigeria. Rita (2015) examined the impact of deposits (current, saving and term) of commercial banks on Gross Domestic Product in northern region of India. 
Norafifah and Sudin (2000) investigate corporate customer perceptions of Islamic Banking Products and Services, it shows that providers of Islamic banking products and services have not done enough to educate customers and market their products. Finally, this study also shows that the most important factor perceived by corporate customers in selecting their banks is the cost of the services and products. In addition, Fada (2012) examine the perceptions of the economic viability of Islamic banking. It reveals that it will bring about economic benefits which will serve as a means for financial inclusion for the financially excluded and will also serve as a potential vehicle for fund mobilization, create more employment opportunities and encourage foreign investment especially from the Middle East amongst others.

Ibrahim et al (2015) also examine customers' perception of Non-Interest Banking Services by Deposit Money Banks: Evidence from Nigeria. The results also indicate that there is no significant difference in perception of customers based on gender, educational qualification and religion. Abdelghani and Hassamuddeem (2012) examine customers' perception and adoption towards Islamic Banking services in Morocco. The results showed that uncertainty, relative advantage, compatibility, awareness as well as subjective norm, have a significant impact on the attitude towards Islamic banking services in Morocco.

Naeem et al (2016), investigates the customer perception toward Islamic banking and its effect on the perception of customers in Pakistan. The result shows that the perception of customers is most important for the success and growth of Islamic banking in Pakistan, religion awareness regarding product and service, awareness to financial teaching of Islam, advertising, networking have the strong impact on the perception of customer regarding Islamic banking.

Moreso, Bare (2016) examine the influence of consumer's awareness on Islamic banking in Nairobi country, Kenya. The results disclosed that majority of the respondent are aware of Islamic banking but only the fundamental concepts of Islamic banking systems and are not aware of the specific Islamic financial services like Musharakah, Murabaha, Ijara, and Qard Hasan. The findings also disclosed that majority of the respondents are aware of Al-wadiah savings and current account and currently operating these account and intend to operate them in the near future.

Fada and Bundi (2012) survey the viewpoints of the people of Gombe Local Government Area to review their perceptions towards Islamic Banking. The survey reveals that the perception of people in the study area is largely consistent with misconception of the subject matter and concludes by calling on relevant stakeholders including the Central Bank to initiate awareness campaign programs to orient and enlighten the public about Islamic Banking, its products, services and economic benefits to be derived from the advent of Islamic banking.

However, existing literatures reviewed focused on the perception of either employee of banks, customers or both towards either the concept of Islamic banking, its patronage or products alone as they have failed to disaggregate the activities or services of Islamic banks and windows based on its processes as a financial intermediary and to link each of this activities to growth in order to ascertain to what extent each have contributed to the growth process and also the works that have been able to established the relationship between Islamic 
banks and economic growth are restricted to GCC countries and MENA countries, therefore their outcome cannot be applicable to the Nigeria context. It is against this background that this research was conducted to fill the vacuum in the literature.

\section{METHODOLOGY}

\subsection{Data}

The study used primary data obtained from employees of the Jaiz bank, Sterling Bank, Stanbic IBTC Bank and Keystone Bank. This data was collected via questionnaire as it was adopted from the works of Iftikhar and Samreena (2016). The population of the study is 7,185 , which constitute the total employees of the banks that practice full- fledged Islamic banking (known as NIB) and conventional Islamic bank windows in Nigeria. These figures were obtained from annual reports of the various banks. See table 3.1 for the breakdown of the population as per each bank.

Non-probability sampling was adopted in this study specifically the purposive sampling in obtaining the total population of the study. In addition, the sample size was obtained via the use of Taro Yamane formula (1976): $\mathrm{n}=\mathrm{N} / 1+\mathrm{Ne}^{2}$. Where;

Table 3.1.

Tabulation of Number of Employee

\begin{tabular}{llc}
\hline S/N & \multicolumn{1}{c}{ Bank's Name } & Number of Employee \\
\hline 1 & Jaiz Bank Plc & 602 \\
2 & Sterling Bank Plc & 2,261 \\
3 & Key Stone Bank & 1,931 \\
4 & Stanbic IBTC & 2,391 \\
& Total & 7,185 \\
\hline
\end{tabular}

Source: Sterling Bank Annual report (2016); Jaiz Bank Plc (2016); StanbicIBTC Annual report (2016); Keystone Bank Annual report (2013).

n: Desired sample size; N: Total Population $(7,185)$; e: Acceptable error limit $(0.05)$. Therefore, the sample size is 379 for this study. In order to distribute the questionnaire to the respondents without bias, the stratified random sampling was further conducted using the formula below: -

Sample size of the strata $=$ Size of the entire sample $\times$ Layer Size Total population size

Consequently, the respondents as per each bank is as thus; 
Table 3.2.

Tabulation of Number of Respondents per Bank

\begin{tabular}{llcc}
\hline S/N & \multicolumn{1}{c}{ Bank's Name } & $\begin{array}{c}\text { No of Employee (Total } \\
\text { Population per Bank) }\end{array}$ & $\begin{array}{c}\text { No. of Respondents per } \\
\text { Bank in the sample }\end{array}$ \\
\hline 1 & Jaiz Bank Plc & 602 & 32 \\
2 & Sterling Bank Plc & 2,261 & 119 \\
3 & Key Stone Bank & 1,931 & 102 \\
4 & Stanbic IBTC & 2,391 & 126 \\
& Total & 7,185 & 379 \\
\hline
\end{tabular}

Source: Authors Computation, 2017

More so, out of the total of three hundred and seventy-nine (379) copies of questionnaire that were administered to the various banks concerned but only three hundred and sixty-seven (367) copies were retrieved making an average of $96.83 \%$ return rate while 12 was unsuccessful. The return rate of about $96.83 \%$ is high which is better and assures more accurate survey results (Aday 1996; Babbie, 1990; Backstrom and Hursh, 1963; Rea and Parker, 1997) and it is above the rule of thumb base line return rate of 55.6\% (Yehuda, 1999).

\subsection{Method}

Logit regression model was used to determine the perception on the contribution of Islamic banks and windows towards the growth of Nigerian economy. A dummy dependent variable (Perception of respondents) was regressed on key variables like loan services and deposit services, which are called the explanatory or independent variable. The logistic model was used because of the nature of data obtained that was qualitative and couple with the responses that are dichotomous. Thus, makes it to fit into the logit model. Logit models are binary (also called dummy) or nonlinear regression model that forces the output (predicted values) to be either 0 or 1 which represent NO and YES respectively in this study. Furthermore, it estimates the probability of the dependent variable to be $1(Y=1)$. This is the probability that some event happens. Additionally, a measure of central tendency (the use of frequency, tables and percentages) was employed and economic software called STATA was used.

\subsection{Model Development}

The model developed for this study derives its root from the works of Abduh and Chowdhury (2012) which in their study, to study to examine the relationship between the development of Islamic banking and economic growth of Bangladesh. The following models were presented:

$$
\begin{aligned}
& \operatorname{Ingdp}_{\mathrm{t}}=\alpha_{0}+\alpha_{1} \ln \mathrm{Ifib}+\mu_{\mathrm{t}} \\
& \operatorname{lntfib} \mathrm{t}_{\mathrm{t}}=\alpha_{0}+\alpha_{1} \operatorname{Ingdp}+\mu_{\mathrm{t}} \\
& \operatorname{Ingdp}_{\mathrm{t}}=\alpha_{0+} \alpha_{1} \text { Intdib }+\mu_{\mathrm{t}} \\
& \text { Intdib }_{\mathrm{t}}=\alpha_{0}+\alpha_{1} \text { Ingdp }+\mu_{\mathrm{t}}
\end{aligned}
$$


Where:

$\begin{array}{ll}\text { Ingdp } & \text { : natural logarithm of real gdp } \\ \text { Intfib } & \text { : natural logarithm of Islamic banks total financing } \\ \text { Intdib } & \text { : natural logarithm of Islamic banks total deposit } \\ \alpha^{\prime} \text { s } & \text { : coefficients } \\ \mu & \text { : disturbance term }\end{array}$

In order to merge the model to a single linear equation (1) and (3) was adopted as presented in equation (5).

$$
\operatorname{Ingdp_{t}}=\alpha_{0}+\alpha_{1} \ln t f i b+\alpha_{2} \operatorname{Intdib}+\mu_{\mathrm{t}}
$$

Taking into considering, the nature of the data (Qualitative in nature) for this study, equation (5) was modified in order to fit in the logit model adopted. This is presented below:

$$
\begin{aligned}
& \text { PeR }=f(\text { Loan Activities, Deposit Activities }) \\
& \text { PeR }=\beta_{0}+\beta_{1} \text { LoA }+\beta_{2} \text { DeA }+\mu_{1}
\end{aligned}
$$

Where:

PeR : Perception of Respondent whether Islamic bank \& windows contributes to growth.

LoA : Loan Activities

DeA : Deposit Activities

Therefore, re-writing the eqn (7) to fit into the logistic function, we then have

$$
\begin{aligned}
& \mathrm{L}_{\mathrm{n}}(\mathrm{p} / 1-\mathrm{P})=\beta_{0}+\beta_{1} \mathrm{X} 1+\beta_{2} \mathrm{X} 2+\mu_{1} \\
& \mathrm{~L}_{\mathrm{n}}(\mathrm{p} / 1-\mathrm{P})=\beta_{0}+\beta_{1} \mathrm{LoA}+\beta_{2} \operatorname{DeA}+\mu_{1}
\end{aligned}
$$

The logit function is the Natural log of the odds that $Y$ equal one of the category. We therefore assume $\mathrm{Y}$ has only two categories and which is coded as 0 and $1 . P$ is defined as the probability that $Y=1$, which measures the probability that the perception of respondent on Islamic banking and windows contributes to growth. $X^{\prime}$ 's could be specific factors like loan and deposit activities. In addition, the study tested the following hypothesis stated in its null form:

$\mathrm{H}_{01}$ : There is no significant contribution of loan activities carried out by Islamic banks and Islamic windows towards Nigeria's growth based on the perception of the respondent.

$\mathrm{H}_{02}$ : There is no significant contribution of deposit activities carried out by Islamic banks and Islamic windows towards Nigeria's growth based on the perception of the respondent. 


\section{RESULTS AND ANALYSIS}

\subsection{Data Description}

A total of 379 copies of questionnaire were administered to the various banks concerned but only 367 copies were retrieved making an average of $96.83 \%$ return rate while 12 was unsuccessful.

Table 4.1.

Socio-Economic Characteristics of the Respondents

\begin{tabular}{|c|c|c|}
\hline Gender & Frequency & Percentage $(\%)$ \\
\hline Male & 257 & 70 \\
\hline Female & 110 & 30 \\
\hline Total & 367 & 100 \\
\hline \multicolumn{3}{|l|}{ Age Bracket } \\
\hline $25-30$ & 257 & 70 \\
\hline $31-35$ & 74 & 20 \\
\hline $36-40$ & 11 & 3 \\
\hline$>40$ & 25 & 7 \\
\hline Total & 367 & 100 \\
\hline \multicolumn{3}{|l|}{ Religion } \\
\hline Islam & 286 & 78 \\
\hline Christianity & 81 & 22 \\
\hline Total & 367 & 100 \\
\hline \multicolumn{3}{|l|}{ Educational Qualification } \\
\hline Diploma/NCE & 99 & 27 \\
\hline First Degree (Eg. B.Sc, B.Ed, HND etc) & 195 & 53 \\
\hline Higher Degree( E.g. Masters, M.Sc, PhD) & 40 & 11 \\
\hline Higher Degree + Prof. Qualification & 33 & 9 \\
\hline Total & 367 & 100 \\
\hline \multicolumn{3}{|l|}{ Units/Dept } \\
\hline Operations & 110 & 30 \\
\hline Marketing & 184 & 50 \\
\hline Others & 73 & 20 \\
\hline Total & 367 & 100 \\
\hline \multicolumn{3}{|l|}{ Designation } \\
\hline Operations Manager & 59 & 16 \\
\hline Branch Manager & 62 & 17 \\
\hline Others & 246 & 67 \\
\hline Total & 367 & 100 \\
\hline \multicolumn{3}{|l|}{ Working Experience } \\
\hline 0-10years & 81 & 22 \\
\hline 11-20years & 246 & 67 \\
\hline 21years and above & 40 & 11 \\
\hline Total & 367 & 100 \\
\hline
\end{tabular}

Source: Authors Computation, 2017 
Research Question 1: Evaluate the perception of the respondents on the role of loan activities carried out by Islamic banks and windows towards growth of Nigeria economy

Table 4.2.

Perception on Loan Activities Carried Out by Islamic Banks and Islamic Windows towards Growth of Nigeria Economy

\begin{tabular}{|c|c|c|c|c|}
\hline $\mathrm{S} / \mathrm{N}$ & Statement & Categories & Frequency & Percentage $(\%)$ \\
\hline \multirow[t]{3}{*}{1} & \multirow{3}{*}{$\begin{array}{l}\text { What is the structure of your bank loan } \\
\text { services? }\end{array}$} & Equity Based & 336 & 92 \\
\hline & & Debt Based & 31 & 8 \\
\hline & & Total & 367 & 100 \\
\hline \multirow[t]{3}{*}{2} & \multirow{3}{*}{$\begin{array}{l}\text { Is your loan services restricted to Muslims } \\
\text { alone or Muslim related companies? }\end{array}$} & No & 367 & 100 \\
\hline & & Yes & 0 & 0 \\
\hline & & Total & 367 & 100 \\
\hline \multirow[t]{3}{*}{3} & \multirow{3}{*}{$\begin{array}{l}\text { Do you think that your bank utilizes } \\
\text { conventional funds so as to aid its liquidity in } \\
\text { rendering its loan activities? }\end{array}$} & No & 275 & 75 \\
\hline & & Yes & 92 & 25 \\
\hline & & Total & 367 & 100 \\
\hline \multirow[t]{3}{*}{4} & \multirow{3}{*}{$\begin{array}{l}\text { Your loan services do not involve Interest (riba) } \\
\text { and instead it adopts the Profit Loss Sharing } \\
\text { ratio. Do you think the PLS has adequately } \\
\text { compensated the riba element? }\end{array}$} & No & 88 & 24 \\
\hline & & Yes & 279 & 76 \\
\hline & & Total & 367 & 100 \\
\hline \multirow[t]{3}{*}{5} & \multirow{3}{*}{$\begin{array}{l}\text { Your bank does not invest in business/services } \\
\text { that are prohibited by shariah (E.g. Alcohol, } \\
\text { Pork and Gambling etc). Do you think it has } \\
\text { affected those economic activities concerned? }\end{array}$} & No & 0 & 0 \\
\hline & & Yes & 367 & 100 \\
\hline & & Total & 367 & 100 \\
\hline \multirow[t]{3}{*}{6} & \multirow{3}{*}{$\begin{array}{l}\text { Do you think that the loan services rendered } \\
\text { by your bank have impacted on the private } \\
\text { consumption of its beneficiaries? }\end{array}$} & No & 40 & 11 \\
\hline & & Yes & 327 & 89 \\
\hline & & Total & 367 & 100 \\
\hline \multirow[t]{3}{*}{7} & \multirow{3}{*}{$\begin{array}{l}\text { Have your loan services have assisted in } \\
\text { promoting business investments amongst } \\
\text { beneficiaries? }\end{array}$} & No & 92 & 25 \\
\hline & & Yes & 275 & 75 \\
\hline & & Total & 367 & 100 \\
\hline \multirow[t]{3}{*}{8} & \multirow{3}{*}{$\begin{array}{l}\text { Do you think that your loan services assisted in } \\
\text { promoting sustainable development projects? }\end{array}$} & No & 62 & 17 \\
\hline & & Yes & 305 & 83 \\
\hline & & Total & 367 & 100 \\
\hline \multirow[t]{3}{*}{9} & \multirow{3}{*}{$\begin{array}{l}\text { On the whole, have your bank's loan activities } \\
\text { contributed towards the growth of Nigeria } \\
\text { economy? }\end{array}$} & No & 84 & 23 \\
\hline & & Yes & 283 & 77 \\
\hline & & Total & 367 & 100 \\
\hline \multirow[t]{7}{*}{10} & \multirow{7}{*}{$\begin{array}{l}\text { Which instruments of loan services do you } \\
\text { think is mostly patronized? }\end{array}$} & Murabahah & 132 & 36 \\
\hline & & $\begin{array}{l}\text { Mudarabah- } \\
\text { Part Finance }\end{array}$ & 51 & 14 \\
\hline & & $\begin{array}{l}\text { Musharakah- } \\
\text { Partnership }\end{array}$ & 26 & 7 \\
\hline & & Ijarah-Rent & 121 & 33 \\
\hline & & $\begin{array}{l}\text { Sukuk- Islamic } \\
\text { bond }\end{array}$ & 22 & 6 \\
\hline & & Itisna'a & 15 & 4 \\
\hline & & Total & 367 & $' 100$ \\
\hline \multirow[t]{3}{*}{11} & \multirow{3}{*}{$\begin{array}{l}\text { Is collateral required to enjoy loan services } \\
\text { from your bank? }\end{array}$} & No & 110 & 30 \\
\hline & & Yes & 257 & 70 \\
\hline & & Total & 367 & 100 \\
\hline
\end{tabular}


Research Question 2: Evaluate the perception of respondent on the role of deposit services carried out by Islamic banks and windows towards growth of Nigerian economy

Table 4.2 shows that under question 1, Islamic banks and windows loan services in Nigeria is equity based because it recorded $92 \%$ of the respondents whereas debt based response recorded $8 \%$. Under question 2, yes recorded $0.0 \%$ whereas no recorded $100 \%$ from the respondent. One can conclude that Islamic bank and windows loan services are not restricted to Muslims alone or Muslims related companies. Under question 3, the respondents revealed that Islamic bank and Islamic windows does not utilize conventional funds to aid its liquidity in its loan activities. This is because for no it recorded $75 \%$ whereas for yes it recorded $25 \%$. Under question 4 , yes recorded $76 \%$ while no recorded $24 \%$. This shows that Islamic loan services does not involved riba and instead it adopts the Profit and Loss sharing ratio that has adequately compensate the riba element.

Question 5, reveals that Islamic banks and windows do not invest in business/ services that involve (Alcohol, Pork and Gambling etc.) and this has affected the businesses concerned. This is because $100 \%$ of the respondents opted for yes response. Under question 6 , yes recorded $89 \%$ where as no recorded $11 \%$. This means that Islamic bank and windows loan services have impacted on the private consumption of its beneficiaries in terms of boasting their purchasing power, creating employment, poverty reduction and increased standard of living etc.

Under question 7, it was revealed that Islamic banks and windows loan services has helped in promoting business investment most especially by financing business activities of the small and medium scale businesses and other businesses. This is because yes recorded $75 \%$, while no recorded $25 \%$.

Under question 9, yes recorded $77 \%$ while no recorded $23 \%$ for male and female respondents. This implies that Islamic bank and windows loan services have contributed to the growth of Nigeria economy. Under question 10, MurabahaSales Contract recorded 36\%, Mudarabah-Part Finance recorded 14\%, MusharakahPartnership recorded 7\%, ijarah recorded 33\%, and Sukuk-Islamic recorded 6\% respondents and Istisna'a recorded 4\%. One can infer that Murabaha-Sales Contract and Ijarah-Rent are mostly used as an instrument of Islamic financing in Nigeria. Under question 11, it shows that Islamic bank and windows lay emphasis on collateral for its loan activities. This is because yes recorded $70 \%$ while no recorded $30 \%$.

Research Question 2: Evaluate the perception of respondent on the role of deposit services carried out by Islamic banks and windows towards growth of Nigerian economy 
Table 4.3.

Perception on Deposit activities Carried Out by Islamic Banks and Windows towards Growth of Nigeria Economy

\begin{tabular}{lllcc}
\hline S/N & \multicolumn{1}{c}{ Statement } & Categories & Frequency & Percentage (\%) \\
\hline 1. & Do you think that Islamic banks and windows & No & 62 & 17 \\
& have the required products to mobilize deposit & Yes & 305 & 83 \\
\multirow{2}{*}{ from surplus areas of the economy? } & Total & 367 & 100 \\
2. & Is Islamic bank and windows deposit been & No & 279 & 76 \\
& mixed with that of the conventional bank & Yes & 88 & 24 \\
& deposit? & Total & 367 & 100 \\
3. $\quad$ Is there any return on deposit so as to & No & 125 & 34 \\
& encourage clients since your bank do not pay & Yes & 242 & 66 \\
& interest? & Total & 367 & 100 \\
4. $\quad$ Is your deposit mobilization services restricted & No & 367 & 100 \\
& to Muslims alone? & Yes & 0 & 0 \\
& & Total & 367 & 100 \\
5. $\quad$ Has the deposit mobilized been used to finance & No & 62 & 17 \\
& critical sectors of the economy in term of & Yes & 305 & 83 \\
& business investments, infrastructure etc? & Total & 367 & 100 \\
6. & If YES, has it contribute to the growth of the & No & 92 & 25 \\
& Nigerian economy? & Yes & 275 & 75 \\
& & Total & 367 & 100 \\
\hline
\end{tabular}

Source: Authors Computation, 2017

Table 4.3 shows that under question 1, Islamic banks and windows have the required products to mobilize deposit from the surplus area of the economy. This is owing to the facts that yes recorded $83 \%$ while no recorded $17 \%$. Under question 2 , Islamic bank and windows do not mix their deposit with that of the conventional deposit because $76 \%$ of the respondents recorded yes while $24 \%$ recorded no.

Under question 3, no recorded 34\% while, yes recorded $66 \%$. One can conclude that there is return on deposit to encourage clients since Islamic bank and windows do not pay interest. Under question 4, its shows deposit mobilization services are not restricted to Muslims or Muslim related companies alone this is because $100 \%$ of the respondents opted for yes option.

Under question 5, yes recorded $83 \%$ while no recorded $17 \%$. One can conclude that deposit mobilized by Islamic banks and windows are being used to finance critical sectors of the economy in terms of business investment, infrastructure financing and among others. Likewise, under question 6, Islamic bank and windows deposit have contributed towards growth of the Nigerian economy. This is because the yes response recorded $75 \%$, while no recorded $25 \%$. 


\subsection{Results}

Table 4.4.

Logit Regression on the Perception of the Contribution of Islamic Banks and Windows towards the Growth of the Nigeria Economy.

\begin{tabular}{lccccc}
\hline \multicolumn{1}{c}{ Variables } & $\begin{array}{c}\text { Coefficients } \\
(\boldsymbol{\beta})\end{array}$ & $\begin{array}{c}\text { Standard } \\
\text { error }(\mathbf{s e})\end{array}$ & Z ratio & Prob & Odds \\
\hline Loan Activities (LoA) & 1.40344 & .4786784 & 2.93 & 0.003 & 4.069175 \\
Deposit activities (DeA) & 1.336874 & .5683878 & 2.35 & 0.019 & 3.807123 \\
Constant & -7.290483 & 1.235761 & -5.90 & 0.000 & .000682 \\
Model $\chi 2=$ & 127.40 & $\mathrm{P}<0.05$ & & & \\
Pseudo $\mathrm{R}^{2}=$ & 0.4765 & & & & \\
$\mathrm{~N}=$ & 367 & & & & \\
\hline Source: Stata version 3.0 output & & & &
\end{tabular}

Table 4.4, reveals the coefficients, their standard errors, the z-statistic, associated p-values, and the odd ratios of the coefficients. The likelihood ratio chi-square of 127.40 with a p-value of 0.000 tells that the model as a whole fits significantly better than an empty model (i.e., a model with no predictors). It can be seen that $\beta_{1}$, and $\beta_{2}$ are statistically significant couple with the fact that its corresponding $\mathrm{p}$-value is less than 0.05 . This is supported by the fact that if the $t$-value is higher than 1.96. It implies that the variable has a significant influence on the dependent variable (y). That is, the higher the $\mathrm{z}$ the higher the relevance of the variable. More so, the Pseudo $\mathrm{R}^{2}$ is 0.4765 , which shows that the model is fit based on the rule of thumb that a McFaddens pseudo R-squared ranging from 0.2 to 0.4 indicates a good model fit.

The logistic regression coefficients give the change in the log odds of the outcome for a one-unit increase in the predictor variable. For every one-unit change in LoA, the log odds of loan activities (LoA) increase by 1.40344. For every one unit change in DeA, the log odds of deposit activities (DeA) increase by 1.336874 which is supported by the probability values of 0.003 and 0.019 that is less than alpha $(\alpha$ $=0.05$ ) level of significance. More so, Since Pro $>$ chi $2=0.0000$ is less than $\alpha=0.05$. Then, the model is good. Meaning all the coefficients in the model are different than zero.

Consequently, the entire entire null hypothesis earlier stated is rejected at $0.05 \%$ level of significance. Meaning there is a significant contribution of loan activities and deposit activities carried out by Islamic banks and windows towards growth of the Nigerian economy.

\subsection{Analysis}

First, the structure of Islamic banking in Nigeria, which the Conventional NIB windows are not an exception is equity based. In other words, they adopt the Profit Loss Sharing principles. Adopting the equity-based structure, Islamic banks, and windows in Nigeria have succeeded in creating jobs either directly or indirectly, promoting innovation, entrepreneurship, and creativity among clients. 
This finding corroborates with the works of Noraini, Salina \& Dzuljastri, (2015), that equity financing involves mutual risk sharing pertaining to the enterprise and an equitable distribution of return, all this results in improved product and service quality for consumers, Improvement in the skill of the labor, promotion of productivity and creativity would provide a catalyst for more economic activity. Productivity leads in improved pricing, hence cheaper output. This would boost the demand for the country's output and as demand for the country's output increase; the circular flow of funds will trigger more economic activities and all economic agents (household, firms and government) will benefit. In addition, equity based of financing promotes achievement of the objectives of sharia that has to do with protect wealth protection, management and distribution.

Second, Islamic bank services in Nigeria is not restricted to Muslims alone or Muslims related companies as it is opened for all customers in respective of religion, sex or tribe. This findings is in compliance with the works of Kahf (2016), Haron, et al, (1994), Yvonne, Goeff and Loonat (2011), Aziz, Rokiah and Ahmad (2012) and Kewuyemi and Kareem (2015) that there is no doubt that Islamic banks can be used by Muslims and non-Muslims alike without a single thing of differentiation and that Islamic banking products and services are gaining popularity among non-Muslims across the globe due to its wider product coverage and ability to traverse the global economic melt-down.

Third, Islamic banks deposit/loans have a significant effect on Nigeria's Gross Domestic Product (GDP) as revealed in the logit regression output where the variables (i.e. deposit and loan activities) have a positive impact on the growth of Nigeria's economy. This was supported by the probability values of variables of 0.003 and 0.019 , which were less than alpha $(\alpha=0.05)$ level of significance. This implies that Islamic banks in Nigeria mobilize deposit from surplus areas of the economy which is seen as wealth accumulation/formation and use such funds to finance critical sectors of like private consumption, business investments of its customers, aid government spending via sukuk to fund developmental projects, agriculture, manufacturing etc. Invariably, these activities contributed to the growth of the Nation's Gross Domestic Product (GDP). More so, this finding is in line with existing literatures like the works of Mobolaji (2011), Abduh and Chowdhury (2012) Tabash and Dhankar (2014), which they concluded that there is a significant impact of Islamic banking on economic growth.

Fourth, Murabaha and Ijarah are the popular instruments of Islamic form of financing that are largely patronized in Nigeria taking into cognizance the userfriendly nature of the products. This finding is in congruence with the works of Gambo (2013) on customer perception of the effectiveness of service quality delivery of Islamic banks in Nigeria which he stressed that murabaha, mudarabah and ijarah are considered as the leading three products in order of customers' preference against other products like sukuk, istisna etc.

Fifth, Islamic banks in Nigeria still lay emphasis on collateral security against lending so as to minimize default despite operating an equity based structure which advocates stressed that operating such structure does not require security. This outcome reflects the compliance of the extant rules-CBN prudential Guideline on secured lending. However, this finding corroborates with the works of Ibrahim (2016) on the permissibility of collateral in Islamic banking which he stressed 
that sharia which is the basis in which the Islamic banks operates permits the acceptance of collateral for its lending which is popularly called as rahn. This can be used in two ways: as a marhun (pure security) or an instrument to facilitate the micro financing. This is further in compliance with the Central Bank prudential guidelines.

Last, Islamic banks in Nigeria have the required products to satisfy the needs of its populace and they encourage their depositors because by paying returns they attract other customers. This shows that its lack of awareness on the part of this customers that limit their patronage in other products as advanced by the works of Usman (2012), Fada (2012), Adeniran (2014) and Norafifah and Sudin (2000) which they all stressed that the lack of awareness is a major issue facing Islamic banks and windows.

\section{CONCLUSION AND RECOMMENDATION}

\subsection{Conclusion}

Islamic banks and windows are still a growing industry in Nigeria, and they are gradually gaining momentum. However, its contribution towards economic growth can never be relegated to the background in totality as it has contributed in financing critical sectors of the economy, supported private consumption directly or indirectly and business investment etc. which was further buttressed by the outcome of the test conducted which show that Islamic banks loan activities has aided economic growth likewise its deposit activities has helped in mobilizing surplus funds thereby contributing in wealth or capital accumulation. This will serve as a boast to its loan activities. Ultimately, the study concluded that there is significant contribution of Islamic banks and windows towards the growth of the Nigerian economy.

\subsection{Recommendation}

Based on the outcome of this study, the recommendations will be presented are made for so as to improve the activities of Islamic banks and windows:

i. Islamic bank practitioners should ensure that the level of public awareness should be increased via proper adverts, enlightenment campaign to market trade unions and association, localizing pamphlets, mass marketing so that the people can see Islamic banks and windows as an alternative form of banking and not religious affairs. This will further boast its loan and deposit drive.

ii. More so, they should develop and roll out more sharia compliant products taking into consideration the peculiarities that exist in every business environment most especially products that will suits the rural dwellers so as to ensure proper financial inclusion.

iii. There is need to also adhere to the debt financing structure in order to have a proper mix since it is permissible in sharia.

iv. There is urgent need to recruit qualified staff to handle their activities as they are inadequate staff in the industry that are well experienced in Islamic banking field and aside that there is also the need to train and retrain the existing staff so that they can be updated with the latest development in the industry. 
v. Taking into cognizance the positive impact of the variables on growth, there is need for the Central Bank of Nigeria (CBN) to roll out intervention fund products that are sharia-complaint to enable Islamic Financial Institutions to participate. This will serve as a boast to Islamic bank to further support its efforts in financing critical sectors of the economy

vi. Government should create an enabling framework or environment for the smooth operations of IFI's (banks) as obtained by the conventional finance banks via proper legislation that could address key issues like tax and other legal issues etc. relating to their investments

vii. Taking into play that this form of financing has impact on the Nigeria economy, it creates the need for CBN to establish an Islamic money and capital market or creating a level playing ground that can accommodate the various forms of Islamic financial instrument as this will go a long way to deepened the market and attracts investments which will add value to the country growth.

viii.There is need for the academics to undertake further studies as thus; disaggregate between Islamic banks and the windows so as to ascertain the rate at which each contributes towards the growth of the Nigeria economy. To undertake a comparative study between Islamic banks and the conventional banks to know how each contributes towards the growth of the Nigeria economy. To use econometric tools via the adoption of quantitative data (Time series data) on the key indicators of Islamic banks so as to obtain how each contributes to growth and the nature of their relationship towards growth.

\section{REFERENCES}

Abduh, M., \& Chowdhury, N.T. (2012). Does Islamic Banking Matter for Economic Growth in Bangladesh? Journal of Islamic Economics, Banking and Finance, 8(3), 105-108.

Ahmad, W. (2008). Islamic Banking in the UK: Opportunities and Challenges. M.Sc Accounting and Finance Thesis submitted to Kingston Business School, Kingston University, London. http://ssrn.com/abstract=1349170, Accessed $13 / 06 / 16$

Ahmed, A. (2010). Global Financial Crisis: An Islamic Finance Perspective. International Journal of Islamic and Middle Eastern Finance and Management, 3(4), 306-322.

Alex, O. (2014). The Role of Banks in Capital Formation and Economic Growth: The Case of Nigeria. Economy Transdisciplinary Cognition,15(1), 103-111.

Al-Zuhayli, W. (2003). Al-Figh Al-Islami wa Adillatuh (Financial Transactions in Islamic Jurispudence). Translated by Mahmoud A. El-Gamal. Beirut: Dar alFikral al-Mouser.

Azmi, S (2015). Development of Islamic Windows of Conventional Banks: Globalltrends. Available at: https://islamicbanker.com/publication/ development-of-islamic-windows-of-conventional-banks. Retrieved on 06/01/2018. 8:05am

Bare, S. (2016). Influence of Consumer's Awareness On Islamic Banking in Nairobi County, Kenya. European Journal of Business and Social Sciences, 4(11), 124- 129 
Central Bank of Nigeria (2011). Guidelines for the Regulation and Supervision Of Institutions Offering Non-Interest Financial Services in Nigeria. Central Bank of Nigeria. 1-13

Dar, H., \& Presley, J. (1999). Islamic Finance: A Western Perspective. International Journal of Islamic Financial Services, 1(1), 3-11.

Deepti, S., \& Mamta, R. (2014). Impact of Saving Deposits of Commercial Banks on GDP. Journal of Applied Research, 4(9), 95-97.

Fada, K.A. (2012). An Exploratory Study of Perceived Economic Viability of Islamic Banking in Gombe Local Government Area, Gombe State, Nigeria. Australian Journal of Business and Management Research,2(8), 41-55.

Fada, K. A., \& Bundi, W. (2012). People's Perception Towards Islamic Banking: A Field work study in Gombe Local Government Area, Nigeria. International Journal of Business, Humanities and Technology, 2(7), 121.

Farahani, G., Sadr, Y., \& Hossein, M.S. (2012).An Analysis of Islamic Bank Financing and Economic Growth: Case Study of Iran and Indonesia. Journal of Economic Cooperation and Development, 34(4), 1- 24.

Furqani, H., \& Mulyany, R. (2009). Islamic Banking and Economic Growth: Empirical Evidence from Malaysia. Journal of Economic Cooperation and Development, 30(2), 59-74.

Gait, A. H., \& Worthington, A.C. (2007). A Primer on Islamic Finance: Definations, Sources, Principles and Methods. University of Wollongong, School of Accounting and Finance working paper series No. 07/05, 1-26.

Gambo, M. (2013). Customer Perception of the Effectiveness of Service Quality Delivery of Islamic Banks in Nigeria: An Evaluation of Jaiz Bank. Journal of Marketing and Consumer Research, 1, 9-16.

George, J., \& Jones, G. (2005). Understanding and Managing Organisational Behaviour. Perception, Attribution and the Management of Diversity-Chapter 4. Prince hall

Haron, S., \& Ahmad, N. (2000). The Effects of Conventional Interest Rates and Rate of Profit on Funds Deposited with Islamic Banking System in Malaysia. International Journal of Islamic Financial Services, 1(4), 1-7.

Haron, S., \& Hasham, B. (2003). Wealth Mobilisation by Islamic Banks: The Malaysian case. International Seminar on Islamic Creation, University of Durham, United Kingdom.

Ibrahim, D., Hauwa, M. K., Bashir, A.D., \& Abdullateef, K. I. (2015). Customers' Perception of Non-Interest Banking Services by Deposit Money Banks: Evidence from Nigeria. American Research Institute for Policy Development,3(2). 57-65.

Ibrahim, M.L. (2016). The Permissibility of Security (Collateral) in Islamic Banking. Journal of Islamic Economics, Banking and Finance, 12(1), 98-119.

Iftikhar, A.H., \& Samreena, A. K. (2016). Objectives of Islamic Finance Achieved by Islamic Banks. AL-ADWA 45:31. 45-60.

Issa, F., Thouraya, T., \& Thierry, K. (2013). The Islamic Finance Promises: Evidence from Africa. Review of Development Finance, 3. 136-151.

Islamic Finance Service Board. (2016). Islamic Financial Services Industry Stability Report: 25. 
Kahf, M. (2016). Can a Non-Muslim Use an Islamic Bank? Available at: www. Aboutislam.net/conseling/ask-the-scholar/financial-issues/non-muslimislamic-bank.

Kewuyemi, \& Kareem, M. (2015). Islam and Civilization Renewal, 6(3), 388-408.

Khan, M. S. (1986). Islamic interest-free Banking. IMF Staff Papers, 33, 1-27.

Lipsey, R. G (1986). An Introduction to Positive Economics. $6^{\text {th }}$ Edition. Weidenfeld and Nelson, London.

Lewis, M., \& Algaoud, L. (2001). Islamic Banking. Edward Elgar, Cheltenham.

Mehboob ul, H. (2007). People's Perceptions Towards the Islamic Banking: A Fieldwork Study on Bank Account Holders Behaviour in Pakistan. 3(4),153-176

Mobolaji, H.I. (2011). The role of Non Interest Bank in National Economic Development. Central Bank of Nigeria Bullion. 35(3):17-23

Naeem, A., Muhammad, T. M., Muhammad, Z.P., Farooq, A., \& Hafiz, M.A. (2016). Factors Influencing the Perception of Customers in Islamic Banking: A Case Study in Pakistan. Review of Management and Business Research, 5(3).

Norafifah, A., \& Sudin, H. (2000). Corporate Customer Perceptions of Islamic Banking Products and Services. Proceedings of the Fifth Harvard University Forum on Islamic Finance: Islamic Finance: Dynamics and Development Cambridge, Massachusetts. Center for Middle Eastern Studies, Harvard University. 137-146.

Noraini, M., Salina, H., \& Dzuljastri, A. (2015). Exploring Application of Equitybased financing through musharakah mutanaqisah in Islamic banks in Malaysia: Perspective from the Industry players. International Journal of Economics, Management and Accounting, 23(2), 241-261

Nwaeze, C., Michael, O., \& Nwabekee, C. (2014). Financial Intermediation and Economic Growth in Nigeria (1992 - 2011). The Macrotheme Review, 3(6), 124.

Rita, P. (2015). Impact of Deposits of Scheduled Commercial Banks on GDP in Northern Region of India. International Journal of Marketing, Financial Services and Management Research, 4 (6), 61-69.

Tabash, I.M., \& Dhankar, R.(2014a). Islamic Finance and Economic Growth: an Empirical Evidence from UAE. Journal of Emerging issues in Economic, Finance and Banking, 3, 1069- 1082.

Tabash, I.M., \& Dhankar, R.(2014b). Islamic Finance and Economic Growth: an Empirical Evidence from Qatar. Journal of Applied Economics and Business, 2(1), 51- 67.

Yehuda, B. (1999). Response Rate in Academic Studies-A Comparative Analysis Human Relations. 52(4), 421-438.

Yvonne, S., Geoff, B., \& Loonat, A. (2011). Consumer Awareness and Usage of Islamic Banking Products in South Africa. SAJEMS NS .14 (3). 